\title{
Estrogen receptor- $\alpha$ and $-\beta$ are expressed throughout postnatal development in the rat and rabbit growth plate
}

\author{
O Nilsson, V Abad ${ }^{1}$, D Chrysis, E M Ritzén, L Sävendahl \\ and $\mathbf{J}$ Baron ${ }^{1}$
}

Pediatric Endocrinology Unit, Department of Woman and Child Health, Karolinska Institutet, Stockholm, Sweden

${ }^{1}$ Developmental Endocrinology Branch, National Institute of Child Health and Human Development, National Institutes of Health, Bethesda, Maryland 20892, USA

(Requests for offprints should be addressed to O Nilsson, National Institute of Child Health and Human Development, National Institutes of Health, Building 10, Room 10N262, 10 Center Drive, MSC 1862, Bethesda, Maryland 20892-1862, USA; Email: ola.nilsson@kbh.ki.se)

\begin{abstract}
Estrogen regulates skeletal growth and promotes epiphyseal fusion. To explore the mechanisms underlying these effects we investigated the expression of estrogen receptor- $\alpha(E R \alpha)$ and $-\beta(E R \beta)$ in rat and rabbit growth plates during postnatal development, using immunohistochemistry. Immunoreactivity for $\operatorname{ER} \alpha$ and $\operatorname{ER} \beta$ was observed in resting zone and proliferative zone chondrocytes at all ages studied for both rat (7, 14, 28 and 70 days of age) and rabbit $(1,7,28$ and 120 days of age). In the rat distal humerus and the rabbit proximal tibia, expression of both receptors in the hypertrophic zone was minimal
\end{abstract}

at early ages, increasing only at the last time point prior to epiphyseal fusion. Expression was rarely seen in the hypertrophic zone of the rat proximal tibia, a growth plate that does not fuse until late in life. Therefore, we conclude that ER $\alpha$ and ER $\beta$ are both expressed in the mammalian growth plate. The temporal and anatomical pattern suggests that ER expression in the hypertrophic zone in particular may play a role in epiphyseal fusion.

Journal of Endocrinology (2002) 173, 407-414

\section{Introduction}

Longitudinal bone growth occurs at the growth plate by a process called endochondral ossification in which cartilage is first formed and then remodeled into bone tissue. The growth plate is composed of three layers: the resting zone, the proliferative zone and the hypertrophic zone. With increasing age, the growth plate undergoes structural and functional changes. The rate of longitudinal bone growth decreases due, in large part, to a decline in chondrocyte proliferation (Kember \& Walker 1971). However, physiological cell death (Roach \& Clarke 1999) may also contribute to the senescence process. These functional senescent changes are accompanied by structural senescent changes. There is a gradual decline in the overall growth plate height, proliferative zone height, hypertrophic zone height, size of hypertrophic chondrocytes, and column density (Kember \& Walker 1971, Walker \& Kember 1972a,b, Kember 1973, Masoud et al. 1986, Hunziker \& Schenk 1989, Farquharson \& Loveridge 1990, Weise et al. 2001). The growth plate undergoes ossification as the final step in the senescence program. This process, epiphyseal fusion, terminates longitudinal bone growth.
In humans, estrogen accelerates skeletal maturation and induces epiphyseal fusion. This role of estrogen was confirmed by the recognition of two rare genetic disorders, estrogen deficiency due to mutations in the aromatase gene (Morishima et al. 1995) and estrogen resistance due to mutations in the estrogen receptor- $\alpha(E R \alpha)$ gene (Smith et al. 1994). In both these conditions, the growth plates fail to fuse at puberty.

Estrogen has similar effects on the growth plate in some other mammalian species, but not in all. In rabbits, estrogen accelerates growth plate senescence and hastens epiphyseal fusion (Weise et al. 2001). Consequently, epiphyseal fusion occurs at the time of sexual maturation. However, this is not the case in most rat bones (Dawson 1925). It has been suggested that this difference between the rat and the rabbit may be due to differences in expression of ER $\alpha$, which is reported to be downregulated at sexual maturation in rat growth plate cartilage but persists in rabbit growth plate cartilage (Kennedy et al. 1999).

To gain insight into the mechanisms by which estrogen causes epiphyseal fusion, we examined the developmental pattern of $E R \alpha$ and $E R \beta$ expression both in rabbit growth 


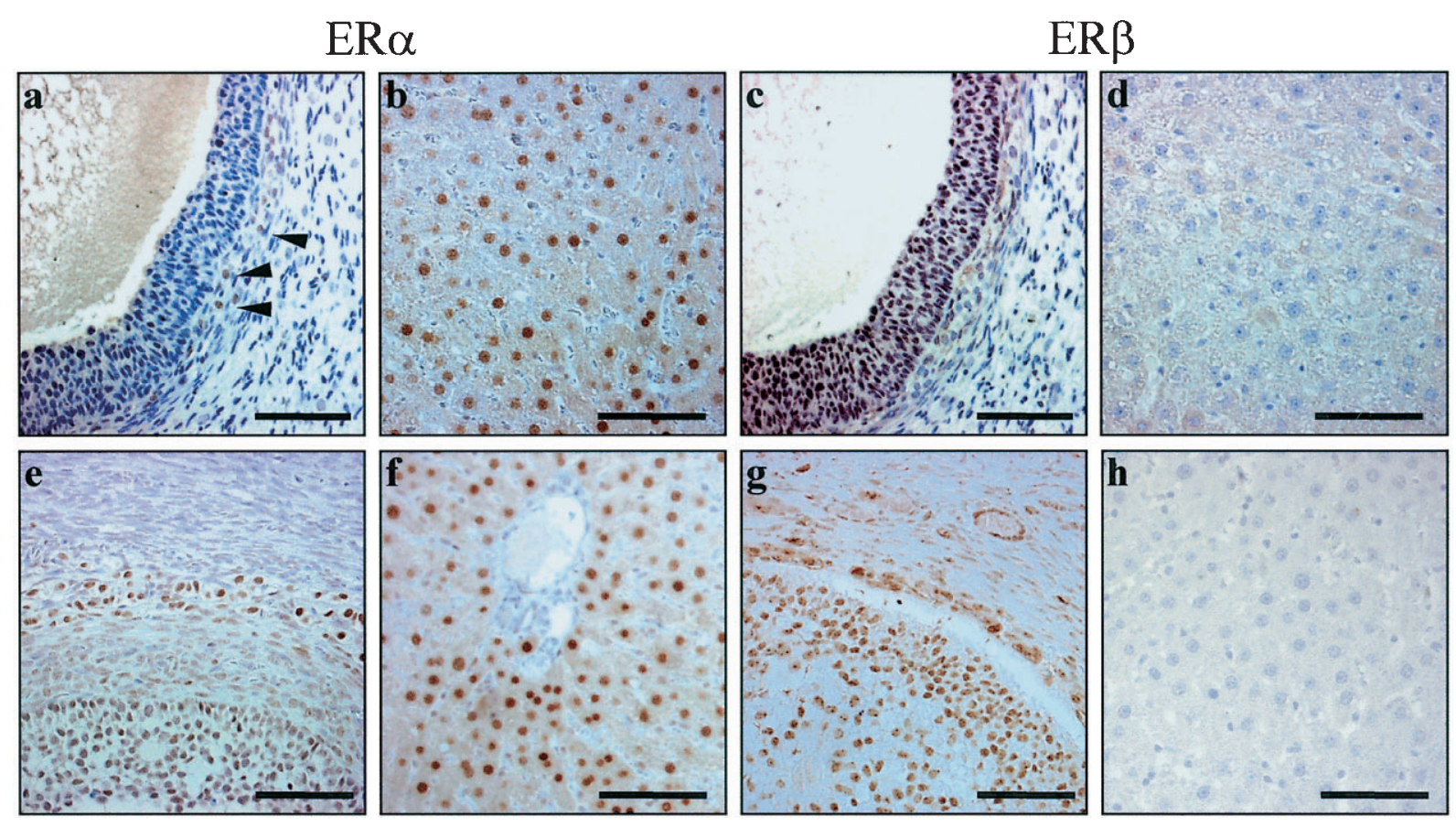

Figure 1 Assessment of $E R \alpha$ and $E R \beta$ antibody specificity. Immunohistochemistry of ER $\alpha$, using the MC-20 antibody (a, b, e, f), and ER $\beta$, using the 06-629 antibody (c, d, g, h). Positive immunoreactivity produces a brown coloration. Sections were counterstained with hematoxylin. In sections of rat $(\mathrm{a}, \mathrm{c})$ and rabbit $(\mathrm{e}, \mathrm{g})$ ovary, ER $\alpha$ was mainly detected in theca cells (arrow heads in (a)) and interstitial glandular cells (e), and ER $\beta$ in granulosa cells (c, g); bar represents $100 \mu \mathrm{m}$. Liver hepatocytes showed immunoreactivity to $E R \alpha(b, f)$, but not to $\operatorname{ER} \beta(d, h)$; bar represents $50 \mu \mathrm{m}$.

plates, which fuse at the time of sexual maturation, and in rat growth plates, some of which fail to fuse at the time of sexual maturation.

\section{Materials and Methods}

Animals and tissue preparation

Male Sprague-Dawley rats (B\&K Universal, Sollentuna, Sweden) and male and female New Zealand White rabbits (Covance Research Products, Denver, PA, USA) were used in the study. Animals were fed freely. In each species, tissues were collected at four different ages, representing different stages of skeletal maturation, with three animals in each group. Male rats were killed at 7, 14, 28 or 70 days of age while male and female rabbits were killed at 1, 7, 28 and 120 days of age. Rats were weaned at the age of 21 days and rabbits at 42 days. The protocol was approved by the Animal Care and Use Committee (National Institute of Child Health and Human Development, US National Institutes of Health) and the Northern Stockholm Animal Ethics Committee respectively.

Tissues were dissected and fixed by immersion in $4 \%$

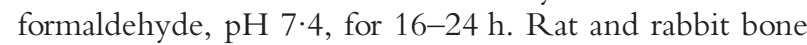
tissue was decalcified in 10\% EDTA and 45\% formic acid respectively. The tissues were embedded in paraffin and cut into $5 \mu \mathrm{m}$ thick sections, mounted on histological glass slides (Superfrost + /+; Menzel-Gloeser, Braunschweig, Germany), dried at $37^{\circ} \mathrm{C}$ overnight and heated at $60^{\circ} \mathrm{C}$ for $1 \mathrm{~h}$.

\section{Immunohistochemistry}

For immunohistochemistry, slides were treated with xylene to remove paraffin and rehydrated in graded alcohol baths. Antigen retrieval was performed in $0.01 \mathrm{M}$ citrate buffer ( $\mathrm{pH} 6 \cdot 0$ ) at $94-97^{\circ} \mathrm{C}$ for $20 \mathrm{~min}$. After one wash in Tris-buffered saline (TBS; $0 \cdot 05 \mathrm{M}$ Tris, $0 \cdot 85 \%$ saline, $\mathrm{pH}$ $7 \cdot 4$ ), endogenous peroxidase activity was reduced by incubation in 3.0\% hydrogen peroxide in TBS for $5 \mathrm{~min}$ at room temperature. To decrease non-specific binding, slides were incubated with 1.0\% BSA (BSA Fraction V Powder; Sigma, St Louis, MO, USA) in TBS at room temperature for $1 \mathrm{~h}$. Primary antibodies were diluted in TBS with $0 \cdot 1 \%$ BSA and sections were incubated overnight at $+4{ }^{\circ} \mathrm{C}$. The same concentrations of primary antibodies were used to stain positive control tissues (ovary and liver) and growth plate tissue.

Control sections were incubated with preabsorbed antibodies, non-specific rabbit $\operatorname{IgG}$ or non-specific mouse IgG1, as described below. Sections were washed five times in TBS, incubated with biotinylated goat anti-rabbit IgG 


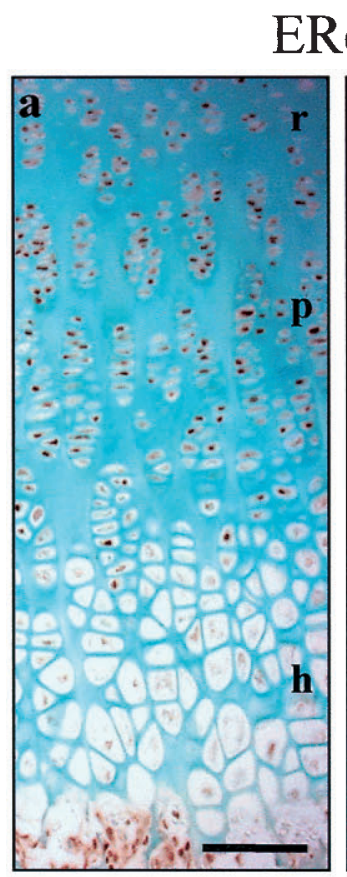

$\mathrm{ER} \alpha$
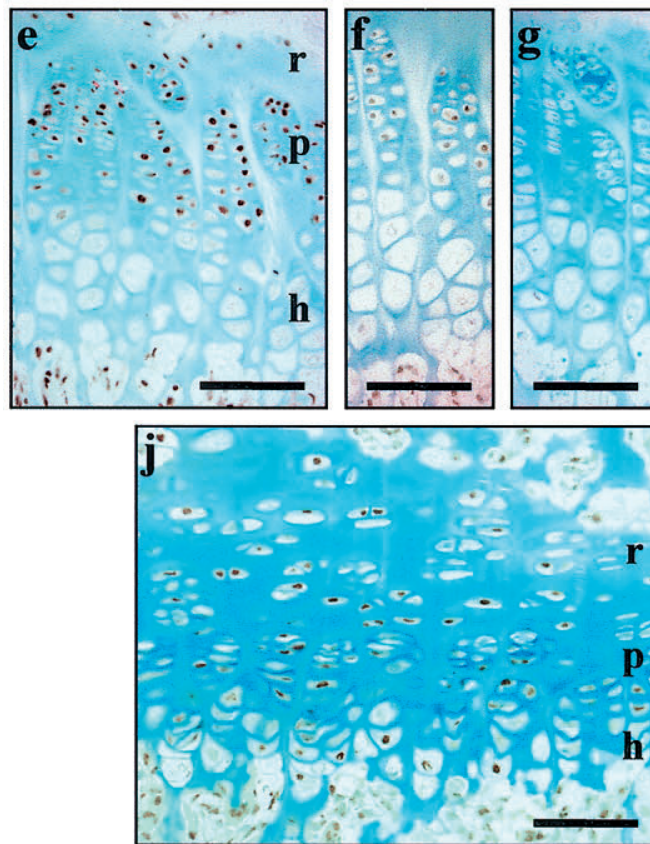

$\mathrm{ER} \beta$
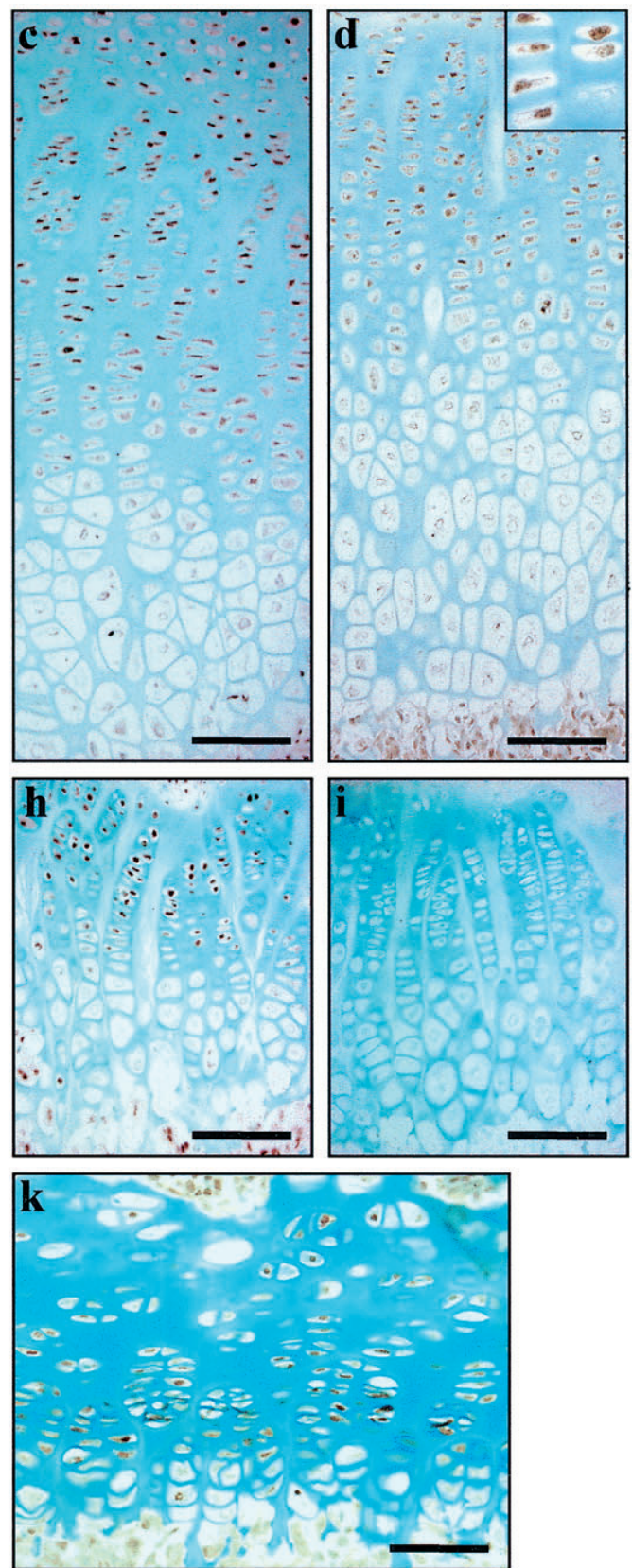

Figure 2 Immunohistochemical localization of ER $\alpha$ and ER $\beta$ in male rat proximal tibial and distal humeral growth plates. Sections of proximal tibial growth plates from 7- (a, c), 28- (b, d, $\times 10, \times 63$ for insets) and 70-day-old (e-i) and distal humeral (j, k) growth plates of 21-day-old male rats immunostained for ER $\alpha$ with the MC-20 (a, $b, e, g, j$ ) or ER-6F11 (f) antibody, and for ER $\beta$ with the 06-629 (c, d, h, i, k) antibody. Immunohistochemical staining produces a brown coloration. The sections were counterstained with methyl-green. When the primary antibodies, MC-20 (g) and 06-629 (i), were preincubated with a corresponding peptide, no nuclear staining was detected. Bar represents $100 \mu \mathrm{m}$. r, resting zone; p, proliferative zone; h, hypertrophic zone. 
(1:200; Vector Laboratories, Burlingame, CA, USA) or goat anti-mouse IgG1 (1:200; Santa Cruz Biotechnology, Inc., Santa Cruz, CA, USA) for $45 \mathrm{~min}$ at room temperature. Sections were washed five times in TBS, incubated with avidin-conjugated peroxidase (Vector Laboratories) for $30 \mathrm{~min}$, and the resulting peroxidase activity was detected using a DAB Kit (Vector Laboratories).

\section{Antibodies}

Anti-ER $\alpha$ For ER $\alpha$ localization, we used an affinitypurified polyclonal rabbit antibody (MC-20: Santa Cruz Biotechnology) and a monoclonal mouse antibody (ER6F11; Novocastra Laboratories Ltd, Newcastle upon Tyne, UK). MC-20, raised against a synthetic peptide corresponding to amino acids $580-599$ of the mouse ER $\alpha$ (ref. NP_031982-1), and amino acids 581-600 of the rat ER $\alpha$ (ref. NP_036821.1), was used at a working dilution of $0 \cdot 2 \mu \mathrm{g} / \mathrm{ml}$. ER-6F11, raised in mouse against the complete human ER $\alpha$ protein, was diluted to $2 \mu \mathrm{g} / \mathrm{ml}$ before use. In all experiments, control slides incubated with nonimmune rabbit IgG or mouse IgG1 were included. As an additional control, MC-20 $(0 \cdot 2 \mu \mathrm{g} / \mathrm{ml})$ was preincubated with the immunizing peptide $(1 \cdot 0 \mu \mathrm{g} / \mathrm{ml})$ for $2 \mathrm{~h}$ at room temperature.

Anti-ER $\beta$ To localize ER $\beta$, a polyclonal rabbit anti-rat ER $\beta$ (06-629; Upstate Biotechnology, Lake Placid, NY, USA), raised against a synthetic peptide corresponding to amino acids $54-71$ of rat ER $\beta$ was used. The optimal working concentration was found to be $5.0 \mu \mathrm{g} / \mathrm{ml}$ for rat tissue and $2.5 \mu \mathrm{g} / \mathrm{ml}$ for rabbit tissue. Control sections incubated with non-immune rabbit $\operatorname{IgG}(5 \cdot 0 \mu \mathrm{g} / \mathrm{ml})$ were included in all experiments. As an additional control, 06-629 was incubated with a 10-fold molar excess of immunizing peptide (629P; Upstate Biotechnology) for $2 \mathrm{~h}$ at room temperature.

\section{Results}

ERa and ER $\beta$ immunoreactivity in control tissues of ovary and liver

To investigate the sensitivity and specificity of the ER $\alpha$ and ER $\beta$ immunostaining, several control experiments were performed using ovary and liver specimens from rats and rabbits.

Nuclear ER $\alpha$ immunoreactivity was detected in theca cells, interstitial gland cells and germinal epithelium in rat and rabbit ovaries (Fig. $1 \mathrm{a}$ and e) using either the polyclonal MC-20 or the monoclonal ER-6F11. No ER $\alpha$ immunoreactivity was detected in granulosa cells of preantral or antral follicles. In contrast to rat ovaries (Fig. 1a), late antral follicles of rabbit ovaries showed faint positive staining for ER $\alpha$ (Fig. 1e). Adjacent sections incubated with normal rabbit IgG or mouse IgG1 did not show a positive immunoreaction.

Positive immunoreactivity for ER $\alpha$ was also found in rat and rabbit hepatocytes using the polyclonal antibody MC-20 (Fig. 1b and $\mathrm{f}$ ) and the ER-6F11 monoclonal antibody (data not shown). In all tissue sections, preabsorption of antibody with immunizing peptide (MC20P) completely abolished the nuclear staining and was similar to normal rabbit IgG and mouse IgG1 controls.

Immunohistochemistry using the polyclonal rabbit antibody 06-629 revealed strong nuclear ER $\beta$ immunostaining in granulosa cells (Fig. 1c and g) and in corpus luteum cells (not shown) of rat and rabbit ovaries. In theca cells and interstitial gland cells no ER $\beta$ immunoreactivity was detected. In sections of rat and rabbit liver, no positive staining for ER $\beta$ could be detected in hepatocytes (Fig. 1d and $\mathrm{h}$ ). When the antibody was preincubated with blocking peptide (06-629P) or substituted for non-specific rabbit $\operatorname{IgG}$, no nuclear staining was detected (data not shown).

Expression of ERa and ER $\beta$ in male rat proximal tibial and distal humeral growth plates

ER distribution was examined in proximal tibial growth plate cartilage of male rats, at postnatal day 7, 14, 28 and 70. With the MC-20 antibody, ER $\alpha$ immunoreactivity was detected in nuclei of resting, proliferative and prehypertrophic chondrocytes at all ages studied (Fig. 2a, b and e). In tibial growth plates, a low number of ER $\alpha-$ positive chondrocytes were found in the hypertrophic zone at any age, but there was a slight increase in the oldest age. A similar pattern of expression, but with slightly weaker intensity, was found with the ER-6F11 antibody (Fig. 2f).

The expression pattern for ER $\beta$ was similar to that of $E R \alpha$, with a strong nuclear staining of a majority of chondrocytes in resting and proliferative zones, but no or only a few positive hypertrophic chondrocytes (Fig. 2c, d and $h$ ). As with ER $\alpha$, both the pattern of expression and the intensity of $\operatorname{ER} \beta$ immunostaining appeared to be constant during development.

In the distal humeral growth plate of 21-day-old rats ER $\alpha$ was detected in resting and proliferative chondrocytes, but also frequently in hypertrophic chondrocytes. The same pattern was seen with both MC-20 (Fig. 2j) and ER-6F11 (not shown) antibodies. ER $\beta$ was detected in a similar pattern, but was less abundant in the hypertrophic zone (Fig. 2k).

\section{Expression of ERa and ER $\beta$ in male rabbit proximal tibial growth plates}

ER distribution was also examined in proximal tibial growth plate cartilage of rabbits, at postnatal day 1, 7, 28 and 120 . In rabbits, as in rats, chondrocytes of the resting 
and proliferative zones showed nuclear immunoreactivity for ER $\alpha$, with the MC-20 (Fig. 3a, b and e) and ER-6F11 (Fig. 3f) antibodies, and for ER $\beta$, with the 06-629 antibody (Fig. 3c, d and h), in growth plate sections of all ages. Cells in the hypertrophic zone showed only faint staining for either ER in the 1- and 7-day-old rabbits. In the 28-day-old group some ER-positive cells were detected in the hypertrophic zone and in the 120-day-old group a majority of the hypertrophic chondrocytes were ER-positive (Fig. 3e, f and h). Sections of rat and rabbit tibial growth plates incubated with non-immune mouse IgG1 (not shown), rabbit IgG (not shown), or antibody incubated with its corresponding immunizing peptide (Fig. $2 \mathrm{~g}$ and $\mathrm{i}$ and Fig. $3 \mathrm{~g}$ and i) showed absence of nuclear staining.

Immunoreactivity to $\operatorname{ER} \alpha$ and $\operatorname{ER} \beta$ was detected in a very similar pattern in tibial growth plates of female rabbits, throughout development (data not shown). In both rats and rabbits, serial sections of tibial growth plates stained for $\operatorname{ER} \alpha$ or $\operatorname{ER} \beta$ showed that the receptors were often detected in the same cells.

\section{Discussion}

We demonstrated ER $\alpha$ and ER $\beta$ immunoreactivity in rat and rabbit growth plates. The findings indicate that both ER subtypes are expressed in resting and proliferative chondrocytes from birth through sexual maturation in both rats and rabbits. This hypothesis is consistent with previous in vivo (Strickland \& Sprinz 1973, Jansson et al. 1983) and in vitro (Corvol et al. 1987, Blanchard et al. 1991) studies, which suggests that estrogen acts directly on growth plate chondrocytes. Our findings are also consistent with a study performed by Gunther et al. (1999), who used an ER antagonist to block estrogen-induced acceleration of skeletal development in a mouse model. That study suggested that the effects of estrogen on skeletal development are mediated through a classical ER.

Both ER $\alpha$ and $\operatorname{ER} \beta$ protein were detected in the growth plate throughout postnatal development. Thus, based on our findings alone, it is not clear which receptor is responsible for the effects of estrogen in the growth plate. However, the striking skeletal phenotype of an ER $\alpha-$ deficient man (Smith et al. 1994) suggests that ER $\alpha$ may play the primary role in humans. Similarly, in mice, skeletal growth is affected primarily by mutations in the ER $\alpha$ rather than the ER $\beta$ gene (Vidal et al. 2000).

The expression of ERs prior to sexual maturation provides an explanation for estrogen responsiveness in early postnatal life, seen, for example, in children with precocious puberty. Therefore the lack of estrogen action on the growth plate in early life is due to lack of ligand, not lack of receptor.

The expression of ERs in the proliferative zone, in particular, provides a possible explanation for the effects of estrogen on chondrocyte proliferation and thus also on the rate of longitudinal bone growth. In rats and rabbits, estrogen decreases proliferation in the proliferative zone and decreases the longitudinal growth rate (Jansson et al. 1983, Weise et al. 2001). In humans, lower doses of estrogen accelerate growth (Martinez et al. 1987), while higher doses may decrease growth rate (Crawford 1978). However, the growth-accelerating effects of estrogen appear to be mediated, at least in part, by increased growth hormone and circulating insulin-like growth factor-I and thus may not involve ERs in the proliferative zone of the growth plate (Metzger \& Kerrigan 1994).

$\operatorname{ER} \alpha$ and $\operatorname{ER} \beta$ protein appeared in the hypertrophic zone shortly prior to fusion in rabbit growth plates and in rat distal humeral growth plates. Expression of ER $\alpha$ in hypertrophic chondrocytes at different developmental stages (Kusec et al. 1998) and ER $\beta$ during puberty (Nilsson et al. 1999) has been described in human growth plates as well. In contrast, ER $\beta$ expression is low in human hypertrophic chondrocytes found in fracture callus (Braidman et al. 2001). The stimulatory effect of estrogen on fusion might involve these ERs in the hypertrophic zone. Hypertrophic chondrocytes undergo physiological cell death (Roach \& Clarke 1999), which precedes and may contribute to ossification. Hypertrophic zone chondrocytes appear to produce factors (Abad et al. 1999) that stimulate angiogenesis and ossification, including vascular endothelial growth factor (Gerber et al. 1999) and fibroblast growth factors (Baron et al. 1994b, Leach et al. 1997). Thus the appearance of ERs in the hypertrophic zone of rabbit tibial and rat humeral growth plates, but to a lesser extent in the rat tibial growth plate, could explain why the former growth plates undergo epiphyseal fusion at the time of sexual maturation while the latter do not.

However, hypertrophic chondrocytes may not be the only cell type mediating the effects of estrogen on epiphyseal fusion. Recent evidence suggests that estrogen may cause fusion indirectly by accelerating growth plate senescence (Weise et al. 2001) and that stem-like cells in the resting zone (Abad et al. 2001) may play a key role in this process. Thus, ERs present in the resting zone may help mediate estrogenic action on growth plate senescence (Baron et al. 1994a, De Luca \& Baron 1999) and epiphyseal fusion.

Our study indicates that the absence of growth plate fusion at sexual maturation in rats is not caused by the disappearance of ER expression in the growth plate. This finding contrasts with those of Kennedy et al. (1999), who compared the expression patterns of $\mathrm{ER} \alpha$ in growth plate cartilage between sexually mature rabbits ( 6 month) and rats (9 week), and found ER $\alpha$ to be expressed in chondrocytes of rabbits but not rats. This difference in results between this previous study and the current study may be due to methodological differences. The previous study used frozen sections for immunofluorescent staining 


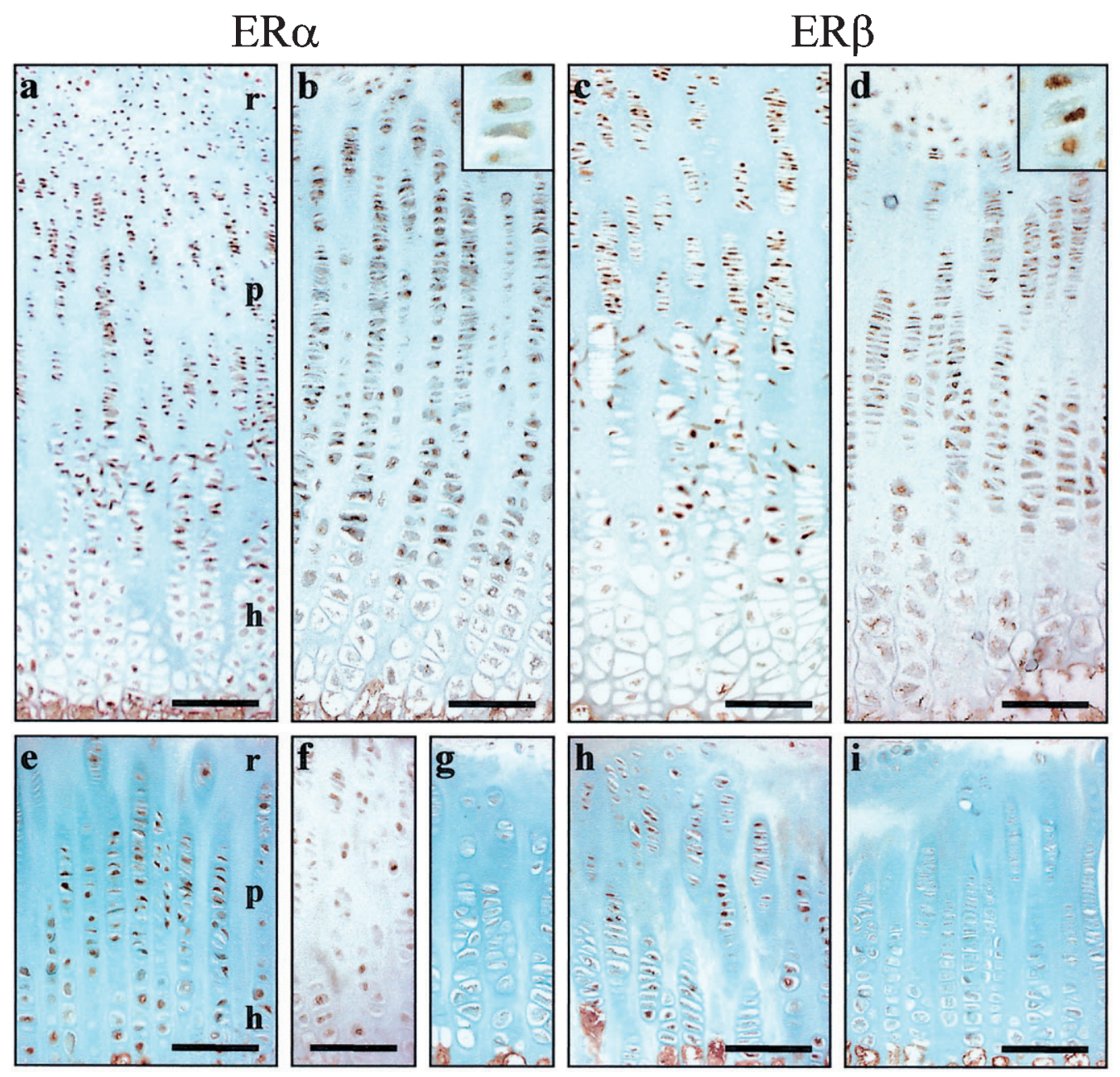

Figure 3 Immunolocalization of ER $\alpha$ and ER $\beta$ in male rabbit proximal tibial growth plates. Immunohistochemistry was performed for ER $\alpha$, using antibody MC-20 (a, b, e, g) or ER-6F11 (f), and ERß, using antibody 06-629 (c, d, h, i), on sections of proximal tibia from 7- (a, c), 28- (b, d, $\times 10, \times 63$ for insets) and 120-day-old (e-i) male rabbits. Preincubation of MC-20 (g) or 06-629 (i) with their corresponding immunizing peptide abolished the nuclear staining. Bar represents $100 \mu \mathrm{m}$. r, resting zone; $\mathrm{p}$, proliferative zone; $\mathrm{h}$, hypertrophic zone.

whereas we used paraffin-embedded tissues with antigen retrieval, a method widely used for immunodetection of nuclear receptors (Taylor 1996). We used two different ER $\alpha$ antibodies to confirm our findings. When we used our immunohistochemical technique to stain liver and ovarian tissue, we found expression patterns that agreed with previous studies (Kuiper et al. 1997, Saunders et al. 1997, Fitzpatrick et al. 1999, Sar \& Welsch 1999). Preabsorption of the polyclonal antibodies (MC-20 and 06-629) with their respective immunizing peptides and use of non-specific immunoglobulins served as negative controls. All of the control experiments suggest that our immunohistochemical staining was specific for $\operatorname{ER} \alpha$ and ER $\beta$.
Alternatively, the difference in results between the current study and that of Kennedy et al. (1999) might be due to selective regulation of specific $\mathrm{ER} \alpha$ isoforms. In addition to the full-length ER $\alpha$, a shorter isoform, truncated from the N-terminal end, is present in osteoblasts (Denger et al. 2001). If growth plate chondrocytes also express shorter isoforms, which are not recognized by all antibodies, then down-regulation of specific isoforms could explain the divergent results.

Our findings also contrast with those of Pinus et al. (1993) who studied estradiol binding in rib cartilage homogenates, demonstrating that estradiol binding decreases during the first month of life. This difference in findings could be due to the non-quantitative nature 
of immunohistochemistry, to the difference in the anatomical site studied, or to a true difference between immunoreactivity and binding capacity.

In summary, our immunohistochemical studies suggest that both ER $\alpha$ and $E R \beta$ proteins are expressed in growth plate chondrocytes throughout development in rat and rabbit growth plate cartilage. This ER expression may explain the effects of estrogen on growth plate cartilage, including the effects on proliferation, growth rate, senescence and epiphyseal fusion.

\section{Acknowledgements}

This study was supported by the Swedish MRC (K200172X-13508-02B), HKH Kronprinsessan Lovisas förening för Barnasjukvård, Stiftelsen Sven Jerrings Fond, Stiftelsen Samariten, Sällskapet Barnavård, and Wera Ekströms Stiftelse.

\section{References}

Abad V, Uyeda JA, Temple HT, De Luca F \& Baron J 1999 Determinants of spatial polarity in the growth plate. Endocrinology 140 958-962.

Abad V, Meyers JL, Weise M, Gafni RI, Barnes KM, Nilsson O, Bacher JD \& Baron J 2001 Localization of the growth plate stemlike cells. In Eighty-third Annual Meeting of the Endocrine Society, p 257. Denver, Colorado.

Baron J, Klein KO, Colli MJ, Yanovski JA, Novosad JA, Bacher JD \& Cutler GB Jr 1994a Catch-up growth after glucocorticoid excess: a mechanism intrinsic to the growth plate. Endocrinology 135 1367-1371.

Baron J, Klein KO, Yanovski JA, Novosad JA, Bacher JD, Bolander ME \& Cutler GB Jr $1994 b$ Induction of growth plate cartilage ossification by basic fibroblast growth factor. Endocrinology 135 2790-2793.

Blanchard O, Tsagris L, Rappaport R, Duval-Beaupere G \& Corvol M 1991 Age-dependent responsiveness of rabbit and human cartilage cells to sex steroids in vitro. Journal of Steroid Biochemistry and Molecular Biology 40 711-716.

Braidman IP, Hainey L, Batra G, Selby PL, Saunders PT \& Hoyland JA 2001 Localization of estrogen receptor beta protein expression in adult human bone. Journal of Bone and Mineral Research 16 214-220.

Corvol MT, Carrascosa A, Tsagris L, Blanchard O \& Rappaport R 1987 Evidence for a direct in vitro action of sex steroids on rabbit cartilage cells during skeletal growth: influence of age and sex. Endocrinology 120 1422-1429.

Crawford JD 1978 Treatment of tall girls with estrogen. Pediatrics 62 1189-1195.

Dawson AB 1925 The age order of epiphyseal union in the long bones of the albino rat. Anatomical Record 31 1-17.

De Luca F \& Baron J 1999 Control of bone growth by fibroblast growth factors. Trends in Endocrinology and Metabolism 10 61-65.

Denger S, Reid G, Kos M, Flouriot G, Parsch D, Brand H, Korach KS, Sonntag-Buck V \& Gannon F 2001 ERalpha gene expression in human primary osteoblasts: evidence for the expression of two receptor proteins. Molecular Endocrinology 15 2064-2077.

Farquharson C \& Loveridge N 1990 Cell proliferation within the growth plate of long bones assessed by bromodeoxyuridine uptake and its relationship to glucose 6-phosphate dehydrogenase activity. Bone and Mineral 10 121-130.
Fitzpatrick SL, Funkhouser JM, Sindoni DM, Stevis PE, Deecher DC, Bapat AR, Merchenthaler I \& Frail DE 1999 Expression of estrogen receptor-beta protein in rodent ovary. Endocrinology 140 2581-2591.

Gerber HP, Vu TH, Ryan AM, Kowalski J, Werb Z \& Ferrara N 1999 VEGF couples hypertrophic cartilage remodeling, ossification and angiogenesis during endochondral bone formation. Nature Medicine 5 623-628.

Gunther DF, Calikoglu AS \& Underwood LE 1999 The effects of the estrogen receptor blocker, Faslodex (ICI 182,780), on estrogenaccelerated bone maturation in mice. Pediatric Research 46 269-273.

Hunziker EB \& Schenk RK 1989 Physiological mechanisms adopted by chondrocytes in regulating longitudinal bone growth in rats. Journal of Physiology 414 55-71.

Jansson JO, Eden S \& Isaksson O 1983 Sites of action of testosterone and estradiol on longitudinal bone growth. American Journal of Physiology 244 135-140.

Kember NF 1973 Aspects of the maturation process in growth cartilage in the rat tibia. Clinical Orthopedics 95 288-294.

Kember NF \& Walker KV 1971 Control of bone growth in rats. Nature 229 428-429.

Kennedy J, Baris C, Hoyland JA, Selby PL, Freemont AJ \& Braidman IP 1999 Immunofluorescent localization of estrogen receptor-alpha in growth plates of rabbits, but not in rats, at sexual maturity. Bone 24 9-16.

Kuiper GG, Carlsson B, Grandien K, Enmark E, Häggblad J, Nilsson S \& Gustafsson JA 1997 Comparison of the ligand binding specificity and transcript tissue distribution of estrogen receptors alpha and beta. Endocrinology 138 863-870.

Kusec V, Virdi AS, Prince R \& Triffitt JT 1998 Localization of estrogen receptor-alpha in human and rabbit skeletal tissues. Journal of Clinical Endocrinology and Metabolism 83 2421-2428.

Leach RM Jr, Sokol C \& McMurtry JP 1997 Immunolocalization of basic fibroblast growth factor in porcine epiphyseal growth plate. Domestic Animal Endocrinology 14 129-132.

Martinez A, Heinrich JJ, Domene H, Escobar ME, Jasper H, Montuori E \& Bergada G 1987 Growth in Turner's syndrome: long term treatment with low dose ethinyl estradiol. Journal of Clinical Endocrinology and Metabolism 65 253-257.

Masoud I, Shapiro F \& Moses A 1986 Tibial epiphyseal development: a cross-sectional histologic and histomorphometric study in the New Zealand white rabbit. Journal of Orthopedic Research 4 212-220.

Metzger DL \& Kerrigan JR 1994 Estrogen receptor blockade with tamoxifen diminishes growth hormone secretion in boys: evidence for a stimulatory role of endogenous estrogens during male adolescence. Journal of Clinical Endocrinology and Metabolism 79 513-518.

Morishima A, Grumbach MM, Simpson ER, Fisher C \& Qin K 1995 Aromatase deficiency in male and female siblings caused by a novel mutation and the physiological role of estrogens. Journal of Clinical Endocrinology and Metabolism 80 3689-3698.

Nilsson LO, Boman A, Sävendahl L, Grigelioniene G, Ohlsson C, Ritzen EM \& Wroblewski J 1999 Demonstration of estrogen receptor-beta immunoreactivity in human growth plate cartilage. Journal of Clinical Endocrinology and Metabolism 84 370-373.

Pinus H, Ornoy A, Patlas N, Yaffe P \& Schwartz Z 1993 Specific beta estradiol binding in cartilage and serum from young mice and rats is age dependent. Connective Tissue Research 30 85-98.

Roach HI \& Clarke NM 1999 'Cell paralysis' as an intermediate stage in the programmed cell death of epiphyseal chondrocytes during development. Journal of Bone and Mineral Research 14 1367-1378.

Sar M \& Welsch F 1999 Differential expression of estrogen receptorbeta and estrogen receptor-alpha in the rat ovary. Endocrinology 140 963-971. 
Saunders PT, Maguire SM, Gaughan J \& Millar MR 1997 Expression of oestrogen receptor beta (ER beta) in multiple rat tissues visualised by immunohistochemistry. Journal of Endocrinology 154 13-16.

Smith EP, Boyd J, Frank GR, Takahashi H, Cohen RM, Specker B, Williams TC, Lubahn DB \& Korach KS 1994 Estrogen resistance caused by a mutation in the estrogen-receptor gene in a man. New England Journal of Medicine 331 1056-1061.

Strickland AL \& Sprinz H 1973 Studies of the influence of estradiol and growth hormone on the hypophysectomized immature rat epiphyseal cartilage growth plate. American Journal of Obstetrics and Gynecology 115 471-477.

Taylor CR 1996 Paraffin section immunocytochemistry for estrogen receptor: the time has come. Cancer 77 2419-2422.

Vidal O, Lindberg MK, Hollberg K, Baylink DJ, Andersson G, Lubahn DB, Mohan S, Gustafsson JA \& Ohlsson C 2000 Estrogen receptor specificity in the regulation of skeletal growth and maturation in male mice. PNAS 97 5474-5479.

Walker KV \& Kember NF 1972a Cell kinetics of growth cartilage in the rat tibia. I. Measurements in young male rats. Cell and Tissue Kinetics 5 401-408.

Walker KV \& Kember NF $1972 b$ Cell kinetics of growth cartilage in the rat tibia. II. Measurements during ageing. Cell and Tissue Kinetics 5 409-419.

Weise M, De-Levi S, Barnes KM, Gafni RI, Abad V \& Baron J 2001 Effects of estrogen on growth plate senescence and epiphyseal fusion. PNAS 98 6871-6876.

Received 24 February 2002

Accepted 27 February 2002 